\title{
Developing virtual simulation games for presimulation preparation: A user-friendly approach for nurse educators
}

Jane Tyerman*1, Marian Luctkar-Flude ${ }^{2}$, Lillian Chumbley ${ }^{3}$, Michelle Lalonde $^{1}$, Laurie Peachey ${ }^{4}$, Tammie McParland $^{4}$, Deborah Tregunno ${ }^{2}$

${ }^{1}$ School of Nursing, University of Ottawa, Ottawa, Canada

${ }^{2}$ School of Nursing, Queen's University, Kingston, Canada

${ }^{3}$ Trent University, Peterborough, Canada

${ }^{4}$ School of Nursing, Nipissing University, North Bay, Canada

Received: February 28, 2021

DOI: $10.5430 /$ jnep.v11n7p10
Accepted: March 8, 2021

Online Published: March 11, 2021

URL: https://doi.org/10.5430/jnep.v11n7p10

\begin{abstract}
Objective: Engaging presimulation activities are needed to better prepare undergraduate nursing students to participate in clinical simulations.

Methods: Design: We created a series of virtual simulation games (VSGs) to enhance presimulation preparation. This involved creating learning outcomes, assessment rubrics, decision point maps with rationale, and filming scripts. Setting: This was a multi-site project involving four universities across Ontario, Canada. Participants: Games were to be embedded within undergraduate nursing courses and used as presimulation preparation before participating in a traditional live simulation. Four existing bilingual peer-reviewed simulation scenarios were transformed into VSGs to be used for presimulation preparation. The team selected critical decision-points from each scenario to form the basis of each VSG, created filming scripts, and filmed and assembled video clips.

Results: Our project generated four bilingual presimulation preparation VSGs with a user-friendly, low-cost VSG design process. Conclusions: We have demonstrated that nurse educators can easily create contextually relevant VSGs addressing program gaps.
\end{abstract}

Key Words: Presimulation preparation, Virtual simulation, Nursing education, Serious games

\section{INTRODUCTION}

Clinical simulation is increasingly being used in health professional education at prelicensure and postgraduate levels. ${ }^{[1]}$ To promote optimal implementation of simulation-based learning activities, the International Nursing Association for Clinical Simulation and Learning (INACSL) developed standards of best practice for simulation. ${ }^{[2]}$ Traditional live simulation involves face-to-face interactions with mannequins and/or embedded actors, where the learner is guided through a scenario in real-time. ${ }^{[3]}$ Often challenging to implement, live simulations are: costly with significant human resources demands; time-intensive as only small group sizes can be accommodated at one time; involve an operational infrastructure; and require formally educated facilitators. ${ }^{[4]}$ These requirements highlight the need for alternative methods to deliver simulation-based educational experiences.

\subsection{Virtual simulation games}

Virtual simulation games (VSGs) are an innovative alternative to traditional live simulations. A combination of screen-

*Correspondence: Jane Tyerman; Email: jtyerman@uottawa.ca; Address: School of Nursing, University of Ottawa, Ottawa, Canada. 
based simulation and serious gaming, VSGs are a recreation of reality depicted on a computer screen for educational purposes, and where player responses can be tracked for assessment purposes. ${ }^{[5]}$ Designed to bridge the gap between theory and evidence-informed practice, virtual simulation has been shown to improve knowledge, satisfaction and selfefficacy among nursing students when compared to traditional forms of learning. ${ }^{[6-10]}$ Within the cognitive domain, virtual game-based learning increases engagement, creative thinking, and decision making. ${ }^{[8]}$ Repetitive simulation learning experiences can improve stored memory, which can be easily retrieved during clinical experiences. ${ }^{[11]}$ Additional advantages of VSGs include ease of access, lower human resource needs, minimized learner vulnerability and anxiety, improved cost-utility, heightened levels of interactivity and realism, engagement, and opportunities for repetitive practice. ${ }^{[12-15]}$ Despite the clear advantages of simulated practice, there are some potential barriers to learning, including fear of technology, ${ }^{[16]}$ cognitive overload, and heightened emotion. ${ }^{[17]}$ Research is needed to explore effectiveness of VSGs on nursing skill acquisition and clinical decision making.

\subsection{Virtual gaming in nursing education}

Current forms of virtual games used in nursing education include online avatars in a $3 \mathrm{D}$ environment; ${ }^{[6,9,18,19]}$ online video-clips with embedded decision making; ${ }^{[10,20]}$ online video recordings with interactive tasks; ${ }^{[21]}$ online medication games with timed medication calculations; ${ }^{[22]}$ and, online triage case studies. ${ }^{[23]}$ Virtual games can be used as a standalone simulation-based learning experience, a method of patient education, or presimulation preparation. ${ }^{[20,24,25]}$

\subsection{Presimulation preparation}

Clinical simulation consists of three phases: presimulation preparation, participation, and debriefing. ${ }^{[26]}$ As a critical component of simulation-based learning, presimulation preparation involves course-related content or material provided specific times in advance of the simulation experience to support learners to achieve learning outcomes. ${ }^{[1]}$ It provides learners with foundational knowledge to promote active participation in the scenario. These activities must align with the learner level, learning objectives and outcomes. ${ }^{[1,2,26]}$

Traditional presimulation preparation may take place in the classroom, skills lab or outside of class time. Preparatory material can be delivered through video and lecturedemonstration, ${ }^{[27]}$ concept mapping and group discussion, ${ }^{[28]}$ interactive internet activities and discussion forums, ${ }^{[29]}$ voiceover PowerPoint lectures and online activities, ${ }^{[30]}$ video discussion, ${ }^{[31]}$ learning modules, ${ }^{[32]}$ or the review of video material. $^{[33]}$

Published by Sciedu Press
Results from a systematic review of presimulation preparation and briefing practices ${ }^{[1]}$ revealed that presimulation preparation has positive outcomes on participant satisfaction and learning outcomes. All studies in the review demonstrated some additional benefits offered by alternative presimulation preparation methods over traditional preparation or no preparation. The level of presimulation preparation should be tailored to the level of the learner related to both clinical and simulation experiences.

\subsection{Virtual simulation games as presimulation prepara- tion}

Presimulation preparation is a critical aspect of simulationbased learning. Despite this, learners often fail to complete traditional presimulation activities, such as assigned readings, which limits their ability to actively participate in the simulation-based learning experience. ${ }^{[1]}$ Thus, there is a need to better engage learners in presimulation preparation to enhance their learning. A potential solution could involve promoting self-regulated learning through virtual simulation. ${ }^{[34]}$ Millennial learners (1982-2004) may be more likely to engage in immersive preparation activities, such as virtual simulations because their preferred learning and communication style is through multi-media. ${ }^{[35]}$ Participation in a VSG prior to a live simulation could provide learners with the opportunity to assess their knowledge prior to participating in the live scenario and set goals for further preparation based on their self-assessed needs.

\subsection{Purpose}

To address this issue, faculty from four Canadian university schools of nursing (Site A, Site B, Site C, Site D) engaged in a collaboration to create an online method of delivering presimulation preparation. The purpose of this project was to develop, implement and evaluate four VSGs in both official languages of Canada, English and French. The research question was to determine the impact of VSGs versus traditional presimulation preparation on nursing students' ability to achieve scenario-specific learning outcomes. This study was a multi-site randomized control trial (RCT) funded through an eCampus Ontario grant, and results of the evaluation will be reported elsewhere. The purpose of this paper is to describe the VSG design process that was created through this project. The feasibility and challenges associated with this process will also be described.

\section{Methods}

Four existing bilingual peer-reviewed simulation scenarios were transformed into VSGs to be used for presimulation preparation. The team selected critical decision-points from each scenario to form the basis of each VSG, created filming 
scripts, and filmed and assembled video clips. Details of each step are described below.

\subsection{Selecting scenarios}

Following a needs assessment of the study sites, scenario topics were selected that corresponded with course needs and the researchers' areas of clinical expertise. Each VSG was derived from a previously developed peer-reviewed simulation scenario created by simulation nurse educators from Ontario, Canada, using the Ontario Simulation Alliance (OSA) simulation design process. ${ }^{[36]}$ This standardized process adheres to the INACSL simulation best-practice standards. ${ }^{[2]}$ Selected game scenarios also represented current health issues relevant within the Canadian context. The VSG topics were: (a) de-escalation of the angry patient (mental health), (b) an older adult diagnosed with urosepsis (acutecritical care); (c) a deteriorating patient in respiratory distress (medical-surgical); and, (d) a young adult diagnosed with diabetic ketoacidosis (pediatric). Each scenario included a self-assessment rubric based on specific scenario learning outcomes (see Table 1). Rubrics were designed for learners to identify knowledge deficits when completed before engaging in the VSG, and as a formative self-assessment tool upon completion of the VSG. Games were to be embedded within undergraduate nursing courses and used as presimulation preparation before participating in a traditional live simulation. It was anticipated that VSGs would enhance student motivation to engage in presimulation preparation when compared to traditional case studies.

\subsection{Assembling the team}

We assembled a team of clinical subject matter experts, who had extensive experience in simulation-based learning and who could contribute vital skills specific to game development and implementation. Core team members previously collaborated on a multi-million-dollar grant funded by the Ontario Ministry of Training Colleges and Universities (MTCU). Each site created their own unique VSG based on a previously validated OSA scenario and learning outcomes assessment rubric. ${ }^{[37]}$ These games were intended to expose students to common experiences faced by nurses in a variety of clinical settings.

\subsection{Faculty development workshop}

A two-day virtual simulation faculty development workshop was hosted at (Site B) in Ontario, Canada. To further support game design and study implementation, guest speakers included: an expert in distance education research; a forensic scientist with extensive experience digitally replicating crime scenes; and two visiting nursing faculty members with VSG filming experience who provided tips on scriptwriting and filming.

At the workshop, an overview of the selected filming technology was provided, including a hands-on demonstration of the Go-Pro video equipment. The research team also established a process for creating gaming critical thinking decision points, developing the learning outcome rubrics, and scriptwriting. The instructional design e-learning specialist on the team reviewed various gaming platforms and determined which best met the needs of the project.

\subsection{Game platform selection}

The development team explored several options for the development of games assessed against five critical criteria ease of use, cost, quality, accessibility, and data collection. From the initial assessment, we were able to narrow it down to three main choices: YouTube, HTML/JavaScript, and Articulate. YouTube was the easiest and most cost-effective. However, it did not have the professional quality we were looking for and limited ability for data collection. Programming the games using HTML and JavaScript would have provided the most control over the final project, including the best quality product and data collection at the lowest cost, but was not a feasible option for development by nontechnical users and replication of the process. We determined Articulate software to be the best option due to the ability for easy replication at a reasonable cost. It also allowed for similar benefits to using HTML/JavaScript in quality and data collection without high requirements of development time and developer expertise.

\subsection{Mapping decision points and responses}

Each critical thinking decision point is based on specific learning objectives. Following an interim video clip depicting a clinical situation, players are required to select the best of three potential responses. We created a template to map each video clip to a decision point and corresponding responses (see Figure 1).

The CAN-Sim Virtual Simulation Game Decision Point Map template guided the development to identify the clinical situation, formulate a critical thinking question, and three responses. Response A is the correct response, while responses $\mathrm{B}$ and $\mathrm{C}$ typically involve common errors or lower priority actions.

The rationale for each of the correct and incorrect responses are provided as embedded feedback for the learner. Decision points and corresponding responses should be reviewed by targeted undergraduate nursing students before scriptwriting to determine the appropriate level of complexity. 
Table 1. Sample Learning Outcomes Assessment Rubric

\begin{tabular}{|c|c|c|c|}
\hline Competency & $\begin{array}{l}\text { Demonstrated attributes align } \\
\text { with required competency }\end{array}$ & $\begin{array}{l}\text { Demonstrated attributes need } \\
\text { some improvement }\end{array}$ & $\begin{array}{l}\text { Demonstrated attributes need major } \\
\text { improvement }\end{array}$ \\
\hline $\begin{array}{l}\text { Collaborate with } \\
\text { team members to } \\
\text { deliver efficient and } \\
\text { effective nursing } \\
\text { care }\end{array}$ & $\begin{array}{l}\text {-Relevant tasks are assigned to } \\
\text { appropriate team members } \\
\text {-Relevant tasks are completed in } \\
\text { a timely manner } \\
\text {-Knowledge and skill are shared } \\
\text { with team members as required } \\
\text {-Assistance is requested from } \\
\text { team members as required }\end{array}$ & $\begin{array}{l}\text {-Some relevant tasks are assigned to } \\
\text { appropriate team members } \\
\text {-Some relevant tasks are completed } \\
\text { in a timely manner } \\
\text {-Knowledge and skill sometimes } \\
\text { shared with team members } \\
\text {-Assistance is sometimes requested } \\
\text { from team members }\end{array}$ & $\begin{array}{l}\text {-Relevant tasks are not assigned to } \\
\text { appropriate team members } \\
\text {-Relevant tasks are not completed in a timely } \\
\text { manner } \\
\text {-Knowledge and skill are not shared with } \\
\text { other team members } \\
\text {-Assistance is never requested from team } \\
\text { members }\end{array}$ \\
\hline \multicolumn{4}{|l|}{ Comments } \\
\hline $\begin{array}{l}\text { Communicate a } \\
\text { critical change in } \\
\text { health status to } \\
\text { secure the } \\
\text { appropriate } \\
\text { collaboration to } \\
\text { treat the patient's } \\
\text { condition }\end{array}$ & $\begin{array}{l}\text {-Delivered data accurately } \\
\text { portrays critical nature of } \\
\text { patient's condition } \\
\text {-Report is effective \& results in } \\
\text { immediate buy-in } \\
\text {-Secured collaboration is } \\
\text { appropriate for the needs of the } \\
\text { patient }\end{array}$ & $\begin{array}{l}\text {-Delivered data somewhat } \\
\text { accurately portrays critical nature of } \\
\text { patient's condition } \\
\text {-Report is somewhat effective \& } \\
\text { results in some buy-in } \\
\text {-Secured collaboration is somewhat } \\
\text { appropriate for the needs of the } \\
\text { patient }\end{array}$ & $\begin{array}{l}\text {-Delivered data does not accurately portray } \\
\text { the critical nature of the patient's condition } \\
\text {-Report is not effective \& results in } \\
\text { little-to-no buy-in } \\
\text {-Secured collaboration is inappropriate for } \\
\text { the needs of the patient }\end{array}$ \\
\hline \multicolumn{4}{|l|}{ Comments } \\
\hline $\begin{array}{l}\text { Perform critical } \\
\text { measures for a } \\
\text { patient experiencing } \\
\text { a decline in health } \\
\text { status to prevent } \\
\text { further deterioration } \\
\text { of the patient's } \\
\text { condition until help } \\
\text { arrives }\end{array}$ & $\begin{array}{l}\text {-Actions reflect a thorough } \\
\text { understanding of significance of } \\
\text { the abnormal findings } \\
\text {-Implements appropriate } \\
\text { emergency measures } \\
\text {-Accesses resources that result in } \\
\text { effective management } \\
\text {-Demonstrates regard for the } \\
\text { urgency of the situation }\end{array}$ & $\begin{array}{l}\text {-Actions reflect some understanding } \\
\text { of significance of abnormal findings } \\
\text {-Implements some appropriate } \\
\text { emergency measures } \\
\text {-Accesses resources that result } \\
\text { in some effective management } \\
\text {-Demonstrates some regard for } \\
\text { the urgency of the situation }\end{array}$ & $\begin{array}{l}\text {-Actions reflect little to no } \\
\text { understanding of significance of the } \\
\text { abnormal findings } \\
\text {-Implements inappropriate } \\
\text { emergency measures } \\
\text {-Accesses resources that do } \\
\text { result in effective management } \\
\text {-Demonstrates little to no regard } \\
\text { for the urgency of the situation }\end{array}$ \\
\hline \multicolumn{4}{|l|}{ Comments } \\
\hline $\begin{array}{l}\text { Identify threats to } \\
\text { patient safety to } \\
\text { minimize the extent } \\
\text { of injury to a patient } \\
\text { experiencing a } \\
\text { decline in health } \\
\text { status }\end{array}$ & $\begin{array}{l}\text {-Effectively carries out safety } \\
\text { checks } \\
\text {-Care demonstrates a regard } \\
\text { for infection control practices } \\
\text {-Demonstrates accountability } \\
\text { for minimizing harm }\end{array}$ & $\begin{array}{l}\text {-Carries out some safety checks } \\
\text {-Care demonstrates some regard for } \\
\text { infection control practices } \\
\text {-Demonstrates some accountability } \\
\text { for minimizing harm }\end{array}$ & $\begin{array}{l}\text {-Fails to carry out safety checks } \\
\text {-Care demonstrates little to no regard for } \\
\text { infection control practices } \\
\text {-Demonstrates little to no accountability for } \\
\text { minimizing harm }\end{array}$ \\
\hline \multicolumn{4}{|l|}{ Comments } \\
\hline $\begin{array}{l}\text { Communicate using } \\
\text { therapeutic } \\
\text { principles to } \\
\text { decrease anxiety in } \\
\text { the patient during an } \\
\text { emergency situation }\end{array}$ & $\begin{array}{l}\text {-Uses a caring demeanour, } \\
\text { resulting in compliance with care } \\
\text {-Interacts with patient in a way } \\
\text { that facilitates open } \\
\text { communication } \\
\text {-Demonstrates a regard for } \\
\text { respecting patient \& family's } \\
\text { right to be informed } \\
\text {-Conveys information to patient } \\
\text { \& family in a way that promotes } \\
\text { understanding }\end{array}$ & $\begin{array}{l}\text {-Uses a somewhat caring } \\
\text { demeanour, resulting in some } \\
\text { compliance with care } \\
\text {-Interacts with patient in a way that } \\
\text { facilitates some open } \\
\text { communication } \\
\text {-Demonstrates some regard for } \\
\text { respecting patient \& family's right } \\
\text { to be informed } \\
\text {-Conveys information to patient \& } \\
\text { family in a way that promotes some } \\
\text { understanding }\end{array}$ & $\begin{array}{l}\text {-Does not use a caring demeanour, resulting } \\
\text { in little to no compliance } \\
\text {-Interacts with the patient in a way that does } \\
\text { not facilitate open communication } \\
\text {-Demonstrates little to no regard } \\
\text { for respecting patient \& family's right to be } \\
\text { informed } \\
\text {-Conveys information to patient \& family in a } \\
\text { way that does not promote understanding }\end{array}$ \\
\hline \multicolumn{4}{|l|}{ Comments } \\
\hline $\begin{array}{l}\text { Use effective } \\
\text { documentation tools } \\
\text { to ensure the events } \\
\text { of the emergency } \\
\text { are appropriately } \\
\text { recorded }\end{array}$ & $\begin{array}{l}\text {-Records details of event in a } \\
\text { timely manner } \\
\text {-Documented data accurately } \\
\text { represent sequence of ensuing } \\
\text { events } \\
\text {-Documentation follows } \\
\text { institutional policy } \\
\end{array}$ & $\begin{array}{l}\text {-Records details of event in a } \\
\text { somewhat timely manner } \\
\text {-Documented data somewhat } \\
\text { accurately represents the sequence } \\
\text { of events; some clarification } \\
\text { needed-Documentation somewhat } \\
\text { follows institutional policy }\end{array}$ & $\begin{array}{l}\text {-Does not record events in timely manner } \\
\text {-Documented data does not accurately } \\
\text { represent the sequence of ensuing events \& } \\
\text { requires extensive clarification } \\
\text {-Documentation does not follow institutional } \\
\text { policy }\end{array}$ \\
\hline comments & & & \\
\hline
\end{tabular}




\begin{tabular}{|c|c|c|c|c|}
\hline \multicolumn{5}{|c|}{ Respiratory Distress Virtual Simulation Game Decision Point Map } \\
\hline $\begin{array}{l}\text { Patient reports } \\
\text { shortness of breath }\end{array}$ & $\begin{array}{l}\text { What is the priority nursing } \\
\text { intervention? }\end{array}$ & $\begin{array}{l}\text { Raise head of the } \\
\text { bed }\end{array}$ & Call MD & $\begin{array}{l}\text { Administer } 022 \mathrm{~L} \text { by } \\
\text { NP }\end{array}$ \\
\hline $\begin{array}{l}\text { Patient reports chest } \\
\text { pain }\end{array}$ & $\begin{array}{l}\text { What is the priority nursing } \\
\text { action? }\end{array}$ & 12 Lead ECG & Administer nitro prn & Call MD \\
\hline $\begin{array}{l}\text { IV heparin infusion is } \\
\text { turned off }\end{array}$ & $\begin{array}{l}\text { What is your first } \\
\text { intervention? }\end{array}$ & $\begin{array}{l}\text { Call MD and ask to } \\
\text { redraw PTT }\end{array}$ & $\begin{array}{l}\text { Restart heparin drip } \\
\text { at previous rate }\end{array}$ & $\begin{array}{l}\text { Complete an } \\
\text { incident report }\end{array}$ \\
\hline \multirow[t]{2}{*}{$\begin{array}{l}\text { Patient has decreased } \\
\text { level of consciousness } \\
\text { and decreased } 02 \text { sat }\end{array}$} & $\begin{array}{l}\text { How will you communicate } \\
\text { to the MD to indicate the } \\
\text { urgency of the situation? }\end{array}$ & $\begin{array}{l}\text { Report concern that } \\
\text { patient's condition is } \\
\text { worsening }\end{array}$ & $\begin{array}{l}\text { Report patient is } \\
\text { stable but family } \\
\text { insisted you call }\end{array}$ & $\begin{array}{l}\text { Request } M D \text { assess } \\
\text { the patient }\end{array}$ \\
\hline & $\begin{array}{l}\text { What are you anticipating is } \\
\text { the root cause of the } \\
\text { patient's distress }\end{array}$ & Pulmonary embolus & $\begin{array}{l}\text { Myocardial } \\
\text { infarction }\end{array}$ & Pneumonia \\
\hline
\end{tabular}

Figure 1. Sample virtual simulation game decision point map

\subsection{Scriptwriting}

Scriptwriting involves describing details of the setting and providing actor direction and specific dialogue between actors. Detailing the scene settings provide the backdrop of each game and include information about the filming scene location (hospital bed, nursing station, etc.), blocking or positioning of actors, and setup of related equipment and props. Direction to actors provides contextual information related to mood, affect, tone of voice, inflection, and emotional response as non-verbal communication must be consistent with the written dialogue.

The final element of scripting involves the dialogue between the actors. Dialogue must flow between and within decision points. It is optimal to develop the script linking interim scenes with all correct decision points first to ensure dialogue aligns. Once the 'correct' scripting has been established, incorrect decision point dialogue can be created. Ensure scripting is realistic and representative of real nurse-patient interactions.

A peer review of the developed script should be completed with content experts. It is suggested that inclusion of current theory educators and lab staff be involved in the review process to ensure content is in alignment with existing course content. The actors should review the script before filming and suggest edits to ensure realism and comfort with dialogue. Final scripts can be embedded within the game as closed captioning or available in a separate document to adhere to accessibility requirements. We found that hiring trained standardized patients was valuable for high-intensity scenarios such as the de-escalation of the angry patient; however, for less emotional scenarios, it was more cost-effective to use family, students, and colleagues as actors.

\subsection{Filming the games}

Equipment was selected based on ease of use and cost. The GoPro Hero 5 Black provided optimal audio-video qual- ity, video stabilization, video or photo options, and an easy method for file transfer. Using the free Capture app, the GoPro camera can be controlled remotely (stop and start filming recording) and filming scenes could be monitored through a live preview and played back externally on a smartphone or iPad. The camera head-mount supports filming from the first-person perspective. Additional accessories such as the handheld monopod and tripod adaptor provide enhanced filming options.

When selecting the filming site, several factors need to be considered to ensure realism or environmental fidelity. The authenticity of nursing labs makes them an ideal. Small and quiet rooms optimize sound quality. Clean, high-quality sound is critical. Larger rooms often result in the camera microphone capturing accessory white noise and echo, which can be difficult to remove during the editing process. The selected location must also have adequate lighting with minimal reflective surfaces. Solutions for poor lighting might include window blinds and curtains. Once each scene has been filmed, it is essential to review the scene to ensure adequate video and audio clarity. It is suggested that each scene be documented in at least two optimal filming takes to offset any unanticipated technical issues. Using a movie clapperboard is fun but also critical to labelling each scene in order to later identify the best takes. A spreadsheet should be used to track the selected scene, including the best takes and the bloopers.

The use of high-fidelity simulators, standardized patients, or volunteer actors needs to align with the virtual simulation game content. Knowledge application in VSGs involves patient observation, interpersonal communication, symptom assessment, diagnosis, management and evaluation. This may be best achieved through the use of actors who can role-play the characteristics of a real patient offering a more realistic opportunity to practice in a simulated virtual environment. 
Some clinical situations necessitate the use of high-fidelity simulators, such as those involving invasive procedures. In these situations, consider a hybrid approach interchanging the use of standardized patients or actors and high-fidelity simulators as appropriate.

Utilizing volunteer actors or drama students can offset the high cost associated with standardized patients with comparable realism. In a study by Luctkar-Flude et al., ${ }^{[38]}$ nursing students enrolled in an undergraduate health assessment course evaluated the use of high-fidelity simulator, standardized patients, and actors. Participants reported feeling most comfortable when interacting with actors and least comfortable with high-fidelity simulators. There is a growing field of researchers applying virtual simulated patients to training and assessment, basic patient communication, interactive conversations, history taking, clinical assessments, and clinical decision-making. ${ }^{[20,39,40]}$

The player perspective is one of the most essential design choices when creating a virtual simulation game. A poten- tial method to increase player presence in gameplay can be achieved through the use of different viewpoints, i.e. consider the value of filming in first-person, second-person, and third-person perspectives. Game video clips filmed from the nurse's perspective (through the eyes of the nurse) result in a higher level of total immersion and is often preferred by players. ${ }^{[41]}$ The second-person viewpoint could provide the patient perspective who is observing the player (nurse). This would be optimal for demonstrating verbal and non-verbal communication skills. Third-person perspective, viewed from a neutral vantage point, may be optimal for observing interprofessional team-based actions.

\subsection{Game assembly}

Individual VSGs were created by the e-learning education developer using the Articulate Storyline $2 \AA$ software (see Figure 2), which allows for game analytics, including the number of attempts, number of incorrect attempts, time spent playing the game, and the number of times each participant accessed the game.

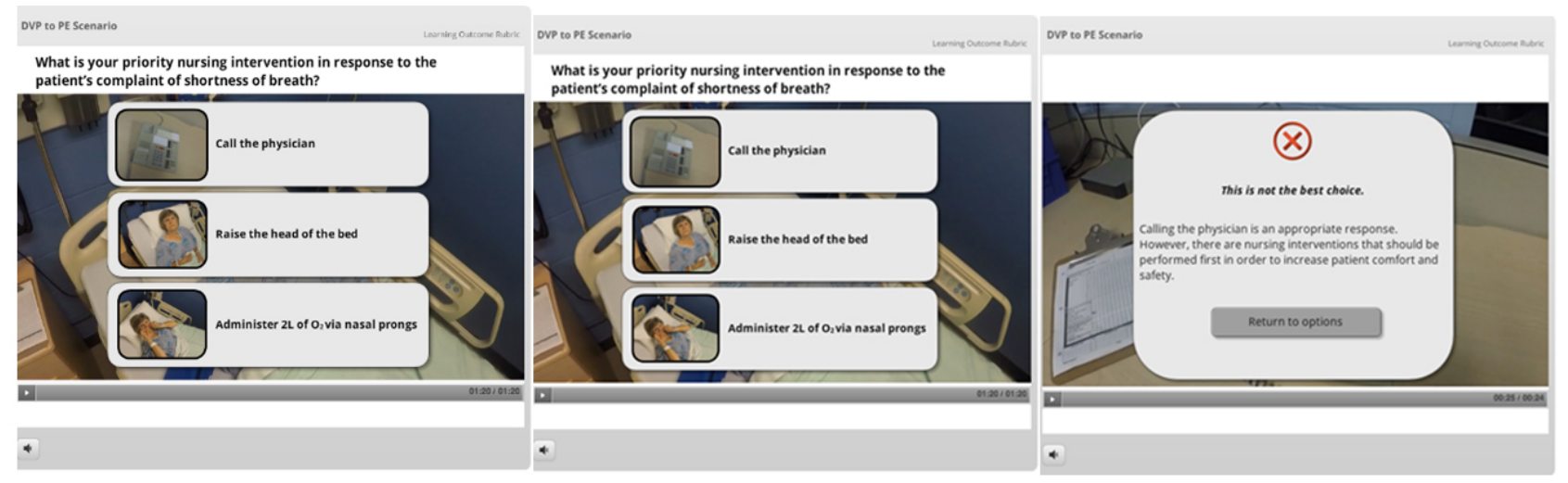

Figure 2. Virtual Simulation Game Screen Shots

Once the games were developed, each game went through a rigorous evaluation process, including content accuracy, validation of rationale related to each decision, and usability testing by three instructors and three students. Once completed, appropriate modifications to each game were made to ensure accuracy and ease of use.

\section{RESUlts}

The tangible results of this project are threefold: (1) creation of bilingual VSGs for presimulation preparation; (2) implementation of VSGs into four schools of nursing; and (3) creation of a user-friendly VSG design process.

The VSG design process we created proved to be efficient and feasible and resulted in the creation of four bilingual VSGs. Two games and their respective live simulations were implemented within existing courses at each of the four col-

Published by Sciedu Press laborating nursing schools (see Table 2). Usability testing and implementation were successful and supported collection of evaluation data that will be reported elsewhere.

Three of the four games are now housed as open-access resources on the CAN-Sim website (http://can-sim.ca/virtualsimulation-games-vsg/virtual-game-preview/) as the Virtual Simulation Games for Presimulation Preparation Series. The fourth game is undergoing updates and will be posted shortly. Each VSG on the website includes (1) link to the VSG; (2) pdf of the in-person simulation scenario; (3) pdf of the presimulation preparation learner package; and (4) pdf of the learning outcomes assessment rubric. Thus, educators have access to all the tools they need to implement both the VSG and the related in-person simulation, including assessment of the learners. 
Table 2. Development and Implementation of Virtual Simulation Games

\begin{tabular}{lllll}
\hline Game/Scenario & Site A & Site B & Site C & Site D \\
\hline Respiratory Distress & Developed \& Implemented & & Implemented & \\
De-escalation of Angry Patient & Implemented & Developed & & Implemented \\
Diabetic Ketoacidosis & & Implemented & Developed \& Implemented & \\
Urosepsis & & Implemented & & Developed \& Implemented \\
\hline
\end{tabular}

Perhaps the most important output of this project was the creation of the VSG design process that has been adapted by CAN-Sim and is now being shared with nurse educators across Canada and the U.S. through in-person and virtual workshops. CAN-Sim has developed its own templates for each stage of VSG design as a result of what was learned during this project. Our process is user-friendly in that it is easily learned by nurse educators with little or no experience in simulation or virtual simulation. We walk participants through writing learning outcomes, assessment rubrics, decision point maps with rationale, and filming scripts. Then we take them through filming video clips with a Go-pro (R) camera and iPad, assembling the VSG, and adding the corresponding text.

\section{Discussion}

\subsection{Lessons learned}

The project was successful in creating presimulation preparation bilingual VSGs that were implemented in multiple undergraduate nursing courses. Additionally, we acquired considerable knowledge and skill in the VSG design process that demonstrates the feasibility of nurse educators creating their own VSGs to align with course and program needs. It was impressive that the team was able to create four bilingual games within a four-month period. With each game, we developed a higher level of efficiency, which streamlined the process and decreased associated costs. Our discussion focuses on the lessons learned.

Although the research team were content experts, we recognized it was important to peer-review scripts prior to filming. This ensured game content and embedded critical decisions aligned with theory, lab, clinical and non-academic requirements (i.e. non-violent crisis intervention course, basic life support).

Team support is essential for the efficient use of time and manpower. This was particularly important for isolated sites. At least one researcher with experience and expertise in filming and game assembly was on-site for the filming of each game. As we progressed, new techniques and skills were acquired and incorporated into the next VSG.

Anticipated time to complete the filming of each game was 16 underestimated, especially for novice game developers. As expertise was developed, the time required to complete each game significantly lessened which impacted the overall cost of creating the VSGs

It was important to ensure that the script flowed authentically between decision points. Thus, it is important to avoid making changes to the script while filming, as any change has the potential to disrupt the flow between decision points. For consistency when filming extended longer than one day, it was essential to take photo images of the actors from all angles, the filming location, equipment, and on-set equipment. This ensured the scene could be replicated on subsequent filming days.

Equipment use and the ability to troubleshoot technical problems is essential. Technical issues can significantly delay filming. The GoPro $\AA$ camera can be voice-activated with various video capture modes. It is essential to understand the appropriate application of each of these modes. Using GoPro accessories posed some unanticipated challenges. For example, the head-mount camera straps require the actor wearing the equipment to keep their head and neck relatively still, resulting in neck and shoulder strain. Even minimal head movement can be visually distracting. It is suggested to mount the camera on a tripod for stabilization.

If filming a game in two languages, it is suggested that after filming each individual clip in one language, the clip should be immediately filmed in the second language. This provides the actors with context to ensure each clip aligns with each other.

For some scenes, still images might be preferable to videos. For example, when creating the de-escalation of the angry patient VSG, it was found that using still images of highly emotional scenes, such restraint use was more appropriate and would decrease the psychological impact for the actor and players viewing the clip.

\subsection{Anticipated impact}

The implementation of VSGs can fill a critical gap in nursing education, especially when facing a global pandemic which has necessitated the transition to online nursing education. The benefits may include the promotion of self- 
regulated learning, enhanced knowledge, decreased learner anxiety, and enhanced preparation for live simulation and clinical practice. The standardization of VSG development reduces faculty preparation and may decrease instruction time required in the simulation laboratory. Further research is needed to confirm these anticipated benefits.

\section{Conclusions}

Through this project, we have developed a user-friendly stepby-step approach to creating VSGs using simple and costeffective methods. Using our process for VSG development, nurse educators can now create content relevant games to fill gaps within their nursing program. Technical expertise is not required, which ensures the cost is minimal. Our development process supports the production of context-relevant VSGs in a cost-effective and timely manner by the content experts themselves. This process will support nurse educators to enhance the quality of innovative nursing education.

\section{FUNDING}

This work was supported by the eCampus Ontario Research and Innovation Grant 2017, Toronto, ON, Canada.

\section{CONFlicts OF InTEREST Disclosure}

The authors declare that there is no conflict of interest.

\section{REFERENCES}

[1] Tyerman J, Luctkar-Flude M, Graham L, et al. A systematic review of health care presimulation preparation and briefing effectiveness. Clinical Simulation in Nursing. 2019; 27: 12-25. https: //doi.org/10.1016/j.ecns. 2018.11.002

[2] INACSL Standards Committee. INACSL standards of best practice: SimulationSM Simulation design. Clinical Simulation in Nursing. 2016; 12(S): S5-S12 https ://doi .org/10.1016/j. ecns. 2016. 09.005

[3] Liaw SY, Palham S, Chan SWC, et al. Using simulation learning through academic-practice partnership to promote transition to clinical practice: a qualitative evaluation. Journal of Advanced Nursing. 2015; 71(5): 1044-1054. PMid:25482494 https://doi.org/10.1 $111 / j$ an. 12585

[4] Haerling KA. Cost-utility analysis of virtual and mannequinbased simulation. Simulation in Healthcare. 2018; 13(1): 33-40. PMid:29373382 https://doi.org/10.1097/SIH. 0000000000 000280

[5] Cant R, Cooper S, Sussex R, et al. What's in a name? clarifying the nomenclature of virtual simulation. Clinical Simulation in Nursing. 2019; 27(C): 26-30 https://doi.org/10.1016/j. ecns. 2018. 11.003

[6] Brull S, Finlayson S, Kostelec T, et al. Using gamification to improve productivity and increase knowledge retention during orientation. JONA: The Journal of Nursing Administration. 2017; 47(9): 448453. PMid:28834805 https://doi.org/10.1097/NNA. 000000 0000000512

[7] Crane A, Tyerman J, Celestini A. Virtual simulation games as an educational tool for university first responders in Canada: A usability study. Clinical Simulation in Nursing. 2021 (in press)

[8] García-Viola A, Garrido-Molina JM, Márquez-Hernández VV, et al. The Influence of Gamification on Decision Making in Nursing Students. Journal of Nursing Education. 2019; 58(12): 718-722. PMid:31794039 https : //doi .org/10.3928/01484834-20191 120-07

[9] Tan AJQ, Lee CCS, Lin PY, et al. Designing and evaluating the effectiveness of a serious game for safe administration of blood transfusion: A randomized controlled trial. Nurse Education Today. 2017; 55: 38-44. PMid:28521248 https://doi.org/10.1016/j.nedt .2017 .04 .027

Published by Sciedu Press
[10] Verkuyl M, Romaniuk D, Atack L, et al. Virtual gaming simulation for nursing education: An experiment. Clinical Simulation in Nursing. 2017; 13(5): 238-244. https://doi.org/10.1016/j.ecns .2017 .02 .004

[11] Turkelson C, Keiser M. Using Checklists and Repetitive Simulation to Improve Patient Safety: A Pilot Project with the Impella $®$ Left Ventricular Assist Device. Clinical Simulation in Nursing. 2017; 13(2): 53-63. https://doi.org/10.1016/j.ecns.2016.10.009

[12] Dang BK, Palicte JS, Valdez A, et al. Assessing simulation, virtual reality, and television modalities in clinical training. Clinical Simulation in Nursing. 2018; 19: 30-37. https ://doi.org/10.1016/j . ecns. 2018.03.001

[13] Drummond D, Hadchouel A, Tesniere A. Serious games for health: Three steps forwards. Advances in Simulation. 2018; 2(3): 1-8. PMid:29450004 https://doi .org/10.1186/s41077-017-003 6-3

[14] Paige JT, Garbee DD, Kozmenko V, et al. Getting a head start: Highfidelity, simulation-based operating room team training of Interprofessional students. Education. 2014; 218(1): 140-149. PMid:24183570 https://doi.org/10.1016/j.jamcollsurg.2013.09.006

[15] Foronda C, Godsall L, Trybulski J. Virtual clinical simulation: the state of the science. Clinical Simulation in Nursing. 2013; 9(8): e279e286. https://doi.org/10.1016/j.ecns.2012.05.005

[16] Al-Ghareeb AZ, Cooper SJ. Barriers and enablers to the use of highfidelity patient simulation manikins in nurse education: an integrative review. Nurse Education Today. 2016; 36: 281-286. PMid:26323885 https://doi.org/10.1016/j.nedt.2015.08.005

[17] Fraser K, Ma I, Teteris E, et al. Emotion, cognitive load and learning outcomes during simulation training. Medical Education. 2012; 46(11): 1055-1062. PMid:23078682 https://doi.org/10.111 $1 / j .1365-2923.2012 .04355 . x$

[18] Boada I, Rodriguez-Benitez A, Garcia-Gonzalez JM, et al. Using a serious game to complement CPR instruction in a nurse faculty. Computer Methods and Programs in Biomedicine. 2015; 22: 282-291. PMid:26319184 https://doi.org/10.1016/j.cmpb. 2015.08 .006

[19] Kardong-Edgren SS, Farra SL, Alinier G, et al. A Call to Unify Definitions of Virtual Reality. Clinical Simulation in Nursing. 2019; 31: 28-34. https://doi.org/10.1016/j.ecns . 2019.02.006

[20] Keys E, Luctkar-Flude M, Tyerman J, et al. Developing a Virtual Simulation Game for Nursing Resuscitation Education. Clinical Sim- 
ulation in Nursing. 2020; 39: 51-54. https ://doi.org/10.1016/ j.ecns.2019.10.009

[21] Sparkes L, Chan MK, Cooper S, et al. Enhancing the management of deteriorating patients with Australian on line e-simulation software: Acceptability, transferability, and impact in Hong Kong. Nursing \& Health Sciences. 2016; 18: 393-399. PMid:27103595 https://doi.org/10.1111/nhs. 12282

[22] Foss B, Lokken A, Leland A, et al. Digital game-based learning: A supplement for medication calculation drills in nurse education. E-Learning and Digital Media. 2014; 11(4): 342-349. https://doi.org/10.2304/elea.2014.11.4.342

[23] Weatherspoon DL, Wyatt TH. Testing computer-based simulation to enhance clinical judgement skills in senior nursing students. Nursing Clinics of North America. 2012; 47: 481-491. PMid:23137600 https://doi.org/10.1016/j.cnur.2012.07.002

[24] Butt AL, Kardong-Edgren S, Ellertson A. Using game-based virtual reality with haptics for skill acquisition. Clinical Simulation in Nursing. 2018; 16: 25-32. https://doi.org/10.1016/j.ecns. 201 7.09 .010

[25] Talley MH, Ogle N, Wingo N, et al. Kaizen: Interactive Gaming for Diabetes Patient Education. Games for Health Journal. 2019; 8(6): 423-431. PMid:31769723 https : //doi.org/10.1089/g4h . 2018.0107

[26] Luctkar-Flude M. Simulation approaches. In P. Bradley \& K. PageCutrara (Eds.). Becoming a Nurse Educator in Canada. Canadian Association of Schools of Nursing (CASN): Ottawa. Forthcoming 2021.

[27] Bowyer MW, Hanson JL, Pimental EA, et al. Teaching breaking bad news using mixed reality simulation. Journal of Surgical Research. 2010; 159: 462-467. PMid:19665731 https://doi.org/10.101 $6 / j \cdot j s s .2009 .04 .032$

[28] Bye BJ. Interactive pre-simulation strategies: Engaging students in experiential learning from the start. Journal of Systemics, Cybernetics and Informatics. 2014; 12(1): 69-75.

[29] Alexander M, Durham CF, Hooper JI, et al. NCSBN simulation guidelines for prelicensure nursing programs. Journal of Nursing Regulation. 2015; 6(3): 39-42. https ://doi.org/10.1016/S215 5-8256 (15) 30783-3

[30] Franklin AE, Sideras S, Gubrud-Howe P, et al. Comparison of expert modeling versus voice-over powerpoint lecture and presimulation readings on novice nurses' competence of providing care to multiple patients. Journal of Nursing Education. 2014; 53(11): 615-622. PMid:25350900 https : //doi .org/10.3928/01484834-20141 023-01

[31] Pucher PH, Aggarwal R, Singh P, et al. Ward simulation to improve surgical ward round performance: A randomized controlled trial of a simulation-based curriculum. Annals of Surgery. 2014; 260(2): 236-
243. PMid:24646529 https://doi.org/10.1097/SLA. 000000 0000000557

[32] Kardong-Edgren S, Starkweather AR, Ward LD. The integration of simulation into a clinical foundations of nursing course: Student and faculty perspectives. International Journal of Nursing Education Scholarship. 2008; 5(1): 26. PMid:18673294 https: //doi.org/10.2202/1548-923X.1603

[33] Nevin M, Neill F, Mulkerrins J. Preparing the nursing student for internship in a pre-registration nursing program: Developing a problem based approach with the use of high fidelity simulation equipment. Nurse Education in Practice. 2014; 14: 154-159. PMid:23958078 https ://doi.org/10.1016/j.nepr.2013.07.008

[34] Derby P. Self-regulated learning in virtual simulations. [Doctoral dissertation, Texas Tech University] TTU DSpace Home_Electronic Theses and Dissertations. 2013. http://hdl . handle.net/2346/ 58645

[35] Nicholas A. Preferred learning methods of the millenial generation. Faculty and Staff-Articles and Papers. 2008; 18 https://digita lcommons.salve.edu/fac_staff_pub/18

[36] Luctkar-Flude M, Tregunno D, Egan R, et al. Integrating a learning outcomes assessment rubric into a deteriorating patient simulation for undergraduate nursing students. Journal of Nursing Education and Practice. 2019; 9(8): 65-73. https ://doi.org/10.5430/jn ep.v9n8p65

[37] Luctkar-Flude M, Tregunno D, Sears K, et al. Reliability and validity of scenario-specific versus generic simulation assessment rubrics. Journal of Nursing Education and Practice. 2020; 10(8): 74-78. https ://doi .org/10.5430/jnep.v10n8p74

[38] Luctkar-Flude M, Baker C, Hopkins-Rosseel D, et al. Development and evaluation of an interprofessional simulation-based learning module on infection control skills for prelicensure health professional students. Clinical Simulation in Nursing. 2014; 10(8): 395-405. https://doi.org/10.1016/j.ecns.2014.03.003

[39] Barnett SG, Gallimore CE, Pitterle M, et al. Impact of a paper vs virtual simulated patient case on student-perceived confidence and engagement. American Journal of Pharmaceutical Education. 2016; 80(1): 1-10. PMid:26941442 https://doi.org/10.5688/ajpe 80116

[40] Gupta A, Singh S, Khaliq F, et al. Development and validation of simulated virtual patients to impart early clinical exposure in endocrine physiology. Advances in Physiology Education. 2018; 42(1): 15-20. PMid:29341815 https://doi.org/10.1152/advan.00110.20 17

[41] Gorisse G, Christmann O, Amato EA, et al. First-and Third-Person Perspectives in immersive Virtual environments: Presence and Performance analysis of embodied Users. Frontiers in Robotics and AI 2017; 4: 33. https://doi.org/10.3389/frobt.2017.00033 